\title{
How Strategic Interaction of Innovation Policies between China's Regional Governments Affects Wind Energy Innovation
}

\author{
Chengming $\mathrm{Li}^{1}{ }^{1}$, Han Shi ${ }^{2, *}$, Liangen Zeng ${ }^{3} \mathbb{C}$ and Xiaomeng Dong ${ }^{4}$ \\ 1 School of Economics, Minzu University of China, Beijing 100081, China; lichengmingpku@163.com \\ 2 School of Economics, Peking University, Beijing 100871, China \\ 3 College of Urban and Environmental Sciences, Peking University, Beijing 100871, China; \\ zengliangen@pku.edu.cn \\ 4 School of New Media, Peking University, Beijing 100871, China; alexandra@pku.edu.cn \\ * Correspondence: pkushihan@163.com
}

check for updates

Citation: Li, C.; Shi, H.; Zeng, L.; Dong, X. How Strategic Interaction of Innovation Policies between China's Regional Governments Affects Wind Energy Innovation. Sustainability 2022, 14, 2543. https://doi.org/ $10.3390 /$ su14052543

Academic Editor: Chia-Lin Chang

Received: 24 January 2022

Accepted: 19 February 2022

Published: 22 February 2022

Publisher's Note: MDPI stays neutral with regard to jurisdictional claims in published maps and institutional affiliations.

Copyright: () 2022 by the authors Licensee MDPI, Basel, Switzerland. This article is an open access article distributed under the terms and conditions of the Creative Commons Attribution (CC BY) license (https:// creativecommons.org/licenses/by/ $4.0 /)$.

\begin{abstract}
Prior research has shown the importance of innovation policies that promote innovation in renewable energy, such as wind power. We study the impact of the strategic interaction of innovation policies between regional governments in terms of wind energy innovation in China. Based on panel data from 2007 to 2018 on a provincial level in China, we construct an innovation strength index of each province in the wind power industry and investigate the inductive effect of the technology-push policy and the demand-pull policy, as well as their spatial spillover effect on wind energy innovation. The results show that the technology-push policy of local governments has an obvious inductive effect on wind energy innovation in the region, while also having a negative spillover effect through $R \& D$ factor competitions between regions with geography proximity or with proximity in the ranking of R\&D funds input. In terms of the demand-pull policy, only changes at the national level can produce positive spillover effects by promoting expectations of market growth. Yet, competition between regions with proximity in the ranking of wind energy resource reserves produce negative spillover effects. The findings should have a far-reaching impact on the sustainable development of global wind power.
\end{abstract}

Keywords: wind energy innovation; strategic interaction; innovation policy; spatial spill over effect; China's wind power market

\section{Introduction}

The Paris Agreement focused on the long-term global goal to limit the rise of global temperatures to below 2 degrees, with further aspirations to get it to 1.5 degrees. This required that governments of the world take actions to tackle the temperature rise. Thus, the "low-carbon growth model" became the consensus of world development. In September 2020, the Chinese government pledged to peak emissions around 2030 and reach carbon neutrality in 2060. To achieve this goal, the development and utilization of green energy is a priority for the Chinese government, and its crux is green innovation [1,2], which can be understood as new or improved processes, technologies, systems, and products to decrease or suppress environmental problems [3-5].

In recent years, the Chinese government has been actively promoting scientific and technological innovation aimed at green development, especially in the field of renewable energy. Since this can lead to economic and environmental benefits, it has become an important aspect of low-carbon economic transformation. The existence of insufficient incentives for the development or promotion of the technology is due to market failure, that is, the market cannot effectively price the externalities of traditional environmental 
problems and the knowledge spillover of $R \& D$ processes, despite the fact that green innovation plays an important role in economic growth in China $[4,6]$.

This phenomenon provides a theoretical basis for policy intervention. During China's 13th five-year plan, the local governments have issued measures to rectify the market failure, including tax incentives, credit subsidies, R\&D subsidies, business concessions and so on, to vigorously support green innovation activities. Many scholars have discussed the effectiveness of these measures for inducing innovation. Yu (2016) found that policy intervention can significantly increase the number of enterprise invention patents [7]. Wang (2016) found that national policies to support industries can effectively induce energysaving and emission reduction [8]. However, $\mathrm{Li}$ (2016) found that the enterprise innovation stimulated by China's industrial policy is more of a "support-seeking" strategic innovation, rather than a real substantive innovation [9].

The aforementioned literatures mainly focus on the implementation effect of innovation policy, and a few of the studies focus on the spillover effect of innovation policy from the perspective of strategic interaction between local governments. The discussion of the strategic interaction between Chinese local governments mainly focuses on the official Championship model based on political performance assessments [10]. In theory, the official tournament is a form of "Yardstick Competition" [11,12], that is, the central government, as a "voter", can vote according to the performance of regional governments relative to other regions. Under the promotion incentive, local governments will refer to the performance of other regional governments when formulating policies. Therefore, the tournament competition between local governments around an assessment index leads to the emergence of strategic interactive behavior. However, so far, Chinese scholars' discussion of the strategic interaction between local governments mainly focuses on the field of economic growth, and few scholars pay attention to the field of green innovation.

In recent years, green development has gradually become an important assessment indicator for local governments and officials. In addition, the emphasis on innovation is rising in China; many governments put up policies to encourage and support innovation activity. The emphasis on innovation promotes the cut-throat competition between local governments and officials; therefore, the innovation policy of the local governments may be affected by a government in an adjacent area. So, when we evaluate the innovation policy, it is necessary to consider the impact of spatial correlation and the spillover effect.

Based on provincial panel data from China's wind power industry from 2007 to 2018, this paper studies the inductive effect of the technology-push policy and the demand-pull policy from local governments in terms of green innovation in the wind energy industry. It then further discusses the inter-provincial spillover effect of the policy and the mode of strategic interaction between governments. The results show that the technology-push policy has an obvious positive inductive effect on wind energy innovation in this region, while it has a negative spillover effect on wind energy innovation through R\&D factor competitions between regions with geography proximity or with proximity in the ranking of R\&D funds input. Due to the small size of the local market, which is negligible compared to the national market, the demand-pull policy has no significant inductive effect on local innovation. However, changes in demand at the national level, rather than the local level, can have a positive spillover effect by raising expectations of demand growth. In this case, there are negative spillover effects through competitions between regions with proximity in the ranking of wind power resource reserves.

The main contributions of this paper are as follows: First, this paper concentrates on the strategic interaction of local governments in the field of green wind energy innovation. By constructing a combination of various spatial weight matrices and policy tools, we analyze the pattern of strategic interaction between local governments and study the mechanism of policy spillover effects. This is intended to provide an understanding of how the demand-pull policy and the technology-push policy affect inter-regional wind energy innovation. Second, the paper focuses on the core patents in the wind energy industry that we are concerned about and uses patent strength rather than patent quantity to represent 
the level of innovation. The statistical caliber of the patent quantity is too wide to ignore the heterogeneity in patent value, so the use of patent strength can avoid the problem of the inductive effect of innovation being overestimated. Third, this paper uses the wind power industry as the analysis object to discuss the effectiveness of the technology-push policy and the demand-pull policy, and clarifies the impact of the strategic interaction between local governments on innovation. This will help local governments sum up their experience and expand to other new energy fields, and promote green innovation and energy structure transformation through the effective use of policy tools.

The paper is arranged as follows: Section 2 features a theoretical analysis and puts forth the research hypothesis. Section 3 features an overview of the research design, data sources, and descriptive statistics. Section 4 focuses on the empirical results. Section 5 includes further discussion about the strategic interaction mode between local governments. Finally, the article concludes the policy implication.

\section{Theoretical Analysis and Research Hypotheses}

The inductive effect of innovation policy on the direction and rate of technological innovation can be explained using two theories [13-15]: the technology-push theory and the demand-pull theory (also known as market-pull theory). According to the technology-push theory, technological innovation comes from the supply side; the basic research, development experiments, and final utilization diffusions are a linear process [16]. Demand-pull theory holds that a predictable market demand can stimulate new research directions, which is the determining factor of technological innovation [17]. In fact, both are indispensable for innovation, which needs to be reasonably coordinated. In addition, the differences in economic sectors also affect the relative importance and effectiveness of the two forces [18]. Such a dichotomy can not only analyze general technological innovation, but also be used to analyze the inductive effect of government policies on green innovation $[4,19]$.

\subsection{The Inductive Effect of Innovation Policies}

\subsubsection{The Inductive Effect of the Technology-Push Policy}

The investment of R\&D funds and advanced training is an important technology-push policy, which, when provided by governments, can rapidly improve their technological capabilities and promote technological innovations [15,20]. Specifically, for the renewable energy industry, the technology-push policy can not only encourage invention but can also reduce cost pressures and further promote cross-sector cooperation and participation, which leads to technology spill overs between industries. A technology-push policy can lead nongovernmental capital to innovations. This positive effect is consistent with empirical studies in the field of renewable energy technology [21-23]. We can assume that the technology-push policy, represented by R\&D investments, has a positive impact on green innovation. Therefore, we can put forward the following hypothesis:

Hypothesis 1. The greater the region's technology-push policy, the higher the region's output of innovation.

\subsubsection{The Inductive Effect of the Demand-Pull Policy}

Some factors, such as price subsidy, the expected market demand, and market regulation, are very important for green innovation to overcome the "double market failure" problem [24]. According to Hicks' "induced innovation" hypothesis, once the relative price of production factors changes, they will promote technological innovation that can use production factors more economically and efficiently. In recent years, with the continuous increase in traditional energy and electricity prices, the government has adopted a lot of financial incentives (including market subsidies and tax relief, etc.). They have issued a new energy act, industrial standards, and market supervision to improve the promotion and application of green technologies. All these have reduced the price disadvantage of green products by changing the relative price between green and non-green products, which has 
stimulated investments in green innovation $[21,25,26]$. By increasing the market demand for green technologies, the policies mentioned above enables enterprises to form market growth prospects. It enables green technology and products be deployed more widely and quickly, thus promoting the generation of innovation $[20,27,28]$. Therefore, we can put forward the following hypothesis:

Hypothesis 2. The stronger the region's demand-pull policy, the higher the region's innovation output.

\subsection{The Strategic Interactions of Innovation Policies between Local Governments and Their Spillover Effects}

Strategic interactions between local governments can be divided into two types: one is the interaction under the spillover effect of policy, the other is the interaction under the effect of resource competition. Between them, the policy spillover effect is the direct formation mechanism of the strategic interaction between local governments, and this effect will directly change the preferences of other local governments. For example, haze pollution control and other general public expenditures all have this kind of spillover effect. Residents in neighboring areas can enjoy public goods provided by other areas, leading to the obvious spatial correlation of local government behaviors [29]. The resource competition effect is an indirect formation mechanism of strategic interaction between local governments. This region is not directly affected by the behavior of other regions, but the flow direction of scarce resources at borders will depend on the relative attraction between regions. As a result, local governments will have to be influenced by other competing regions to compete for those resources, such as tax competitions [29] and welfare competitions [30,31]. In addition, there are some phenomena that combine both mechanisms, such as the ruler competition. Due to information spill over, voters can compare the performance of their local government relative to that of other regional governments and then vote. This creates a scale effect that local governments use to make their fiscal policy based on the performance of other regional governments over the same period or earlier. As for China, the central government is the "voter" who has the right to decide the official's political promotions, resource allocations, and so on. Under this incentive, each region conducts a tournament around a certain assessment index.

\subsubsection{The Strategic Interactions of the Technology-Push Policy between} Local Governments

Due to the limited resources in each region and the pressure of assessment indicators formulated by the central government (such as R\&D funds input, the number of patents, etc.), different regions are facing fierce competition for innovation resources. The innovation policy of a region will also cause the flow of innovation resources in adjacent regions, and then produce the spillover effect between regions [32,33]. At present, to develop an economy, each region mainly competes with other resources, such as talents and technology. Each region implements a technology-push policy, such as R\&D grants or subsidies, to release positive signals to the market and attract $R \& D$ personnel to carry out $R \& D$ activities in the region. Due to the scarcity of $R \& D$ personnel in China, the talent market is in short supply. Therefore, the inflow of talent in one region means an outflow of talent in another region, and technology-push policies in some regions will have negative effects on others region. In particular, regions with insufficient innovation capacities, also known as innovation depressions, have the disadvantage of knowledge capital stock, which makes it difficult to retain local talents and attract non-local talents. As for regions with geographical proximity or regions with proximity in the ranking of $R \& D$ funds input, their policies have a negative effect on their neighbors. Therefore, since there will be strategic interactions between regions in terms of the technology-push policy and negative spillover effects on innovation, we can put forward the following hypothesis. 
Hypothesis 3. For regions with geographical proximity or regions with proximity in the ranking of $R \mathcal{E} D$ funds input, the greater the intensity of technology promotion policies in neighboring regions, the lower the local innovation output.

\subsubsection{The Strategic Interactions of Demand-Pull Policy between Local Governments}

If different regions are similarly ranked in endowment, their basic conditions for industrial development are relatively similar [34]. When the central government controls the total market demand, it is easier for different regions to compete for project approval and construction. Therefore, under the demand-pull policy, the strategic interaction between regions will produce negative spillover effects due to competitive factors. In addition, the flow of products in different regions in China is mainly affected by transportation conditions, and there is no obvious restriction on trade between regions. China is a unified big market [35], and there are few obstacles to the flow of factors and products in interregional markets. Therefore, the local market demand and the market demand of regions with geographical proximity constitute the market demand, which means that demand expansion does not necessarily need to occur in the local region. The demand expansion of regions with geographical proximity, under the demand-pull policy, will also bring about the expected growth of the local market demand, which will induce regional innovation through the spillover effect. Therefore, we can put forward the following hypothesis:

Hypothesis 4. The stronger the intensity of the demand-pull policy of regions with geographical proximity, the higher the local innovation output, while the stronger the demand-pull policy intensity of regions with proximity in the ranking of wind energy resource reserves, the lower the local innovation output.

In conclusion, based on the above discussion, the strategic interaction modes of innovation policies between regions are as Figure 1 shows:

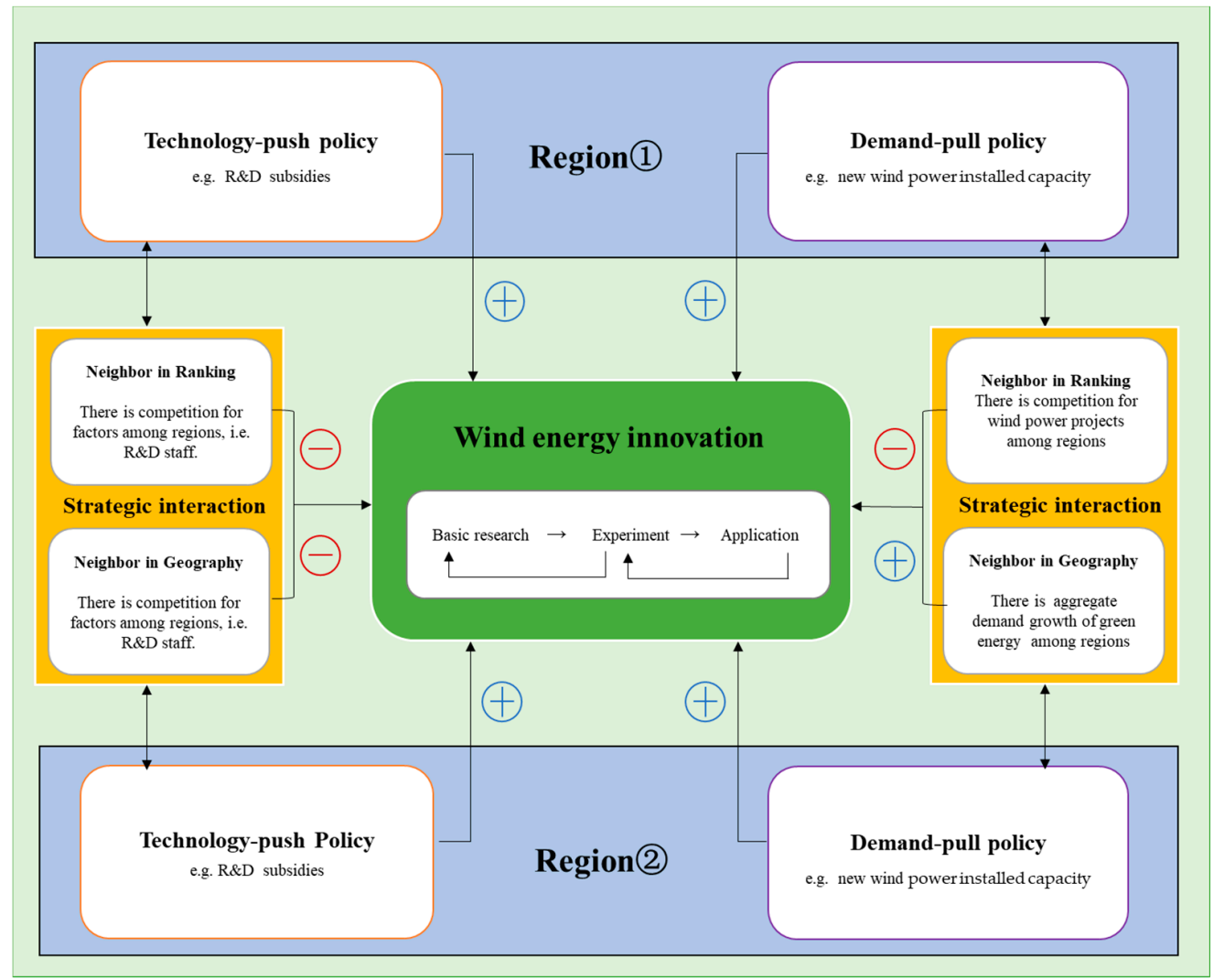

Figure 1. The theoretical logic diagram of this paper. 


\section{Materials and Methods}

\subsection{Model Setting}

Based on the data of the wind power industry in China, this paper first considers the influence of technology-push policies and demand-pull policies on innovation, namely, the inductive effect of innovation policies. Furthermore, due to spillover effects of the technology-push policy and demand-pull policy on the neighbors, we explore how the spillover effects impact regional green innovation. Therefore, we refer to Gallaher et al. (2021) [36], Huang et al. (2021) [37], and Zhao et al. (2020) [38] using the spatial Dubin model, with two types of policy variables and their spatial lag terms, to explore the impact of strategic interactions between local governments on innovation. The model is set in the following form:

$$
\begin{gathered}
\text { Patent }_{i, t}=\alpha_{i}+\beta_{1} R D_{i, t-1}+\rho_{1} \sum_{j} \omega_{i j}^{g e o} R D_{j, t-1}+\rho_{2} \sum_{j} \omega_{i j}^{r a n k} R D_{j, t-1} \\
+\beta_{2} d A C C z_{i, t-1}+\rho_{3} \sum_{i} \omega_{i j}^{g e o} d A C C z_{j, t-1}+\rho_{4} \sum_{i} \omega_{i j}^{r a n k} d A C C z_{j, t-1}+\sum_{k} \beta_{k} X_{i j}^{k}+\varepsilon_{i, t}
\end{gathered}
$$

In the model (1), Patent $t_{i t}$. is patent strength in wind power, which will be described in detail below, and $i$ and $j$ denote the $i$-th province and $j$-th year. $R D_{i, t-1}$ is the technologypush policy and $d A C C z_{i, t-1}$ is the demand-pull policy, and they will be described in variable selection and definition. The explanatory variables are all lagging in one period. $X$ is the control variable, including local electricity price, the supply rate of thermal power, the rate of population growth, and the consumption level of local residents. $\omega_{i j}=0$ or 1 denotes the spatial weight and will be described in detail below.

Spatial weight matrix $W$ is the focus of this paper. Different categories of spatial weight define different forms of mutual adjacency between spatial objects. Different spatial weight matrices have different economic meanings, so their empirical results are different. In addition to using adjacent relationships in geography, we can also choose economic, social, and resource adjacent relationships. At present, most studies on spatial effects only consider a certain spillover effect, so they only use a certain weight matrix, such as in Moreno et al. (2005) [39]. However, innovation policy formulation is a complex process, and there are multiple spatial correlations between different regions at the same time. Under the official evaluation system, for example, local government's potential competitors are not only geographical neighbors, but are more likely to be the regions with proximity in the ranking of a certain indicator. Local governments will strive to ensure that there is no significant lag behind the average performance of other regions, so they will be influenced by the policies of other regions when formulating corresponding policies, resulting in spatial relevance.

Baicker (2005) pointed out that we can study different strategic interactions between local governments by examining different adjacent relationships, that is, by setting up different spatial weight matrices, which helps to better understand the internal mechanism of the studied problems [40]. The model in this paper also includes multiple spatial weight matrices to study the influence of regional strategic interaction and its internal mechanism. Referring to Yu et al. (2016) [7], this paper constructs two types of spatial proximity weight matrices: geographical and economic. The former is an adjacent relationship in geography, denoted by $W^{g e o}$. The latter is an adjacent relationship in the ranking based on a certain indicator, such as R\&D funds input and wind energy resource reserves, denoted by $W^{\text {rank }}$. and $W^{r a n k^{\prime}}$, respectively. As for adjacent relationships in geography, if the region $i$ and the region $j$ share a common geographical boundary, the spatial weight equals 1 , i.e., $\omega_{i j}^{g e o}=1$, otherwise, $\omega_{i j}^{g e o}=0$. As for adjacent relationships in the ranking based on a certain indicator, if the region $i$ and the region $j$ are next to each other in the ranking, i.e., $i$ precedes or follows $j$, the spatial weight equals 1 , i.e., $\omega_{i j}^{r a n k}=1$ or $\omega_{i j}^{r a n k^{\prime}}=1$, otherwise, $\omega_{i j}^{\text {rank }}=0$ or $\omega_{i j}^{r a n k^{\prime}}=1$. Finally, we standardize the spatial weight matrix so that the sum of elements in each row of the matrix is equal to 1. 


\subsection{Variable Selection and Definition}

\subsubsection{Innovation Variable}

Patent is an important indicator when measuring innovation outputs [41]. Most scholars use the number of patents in the statistical yearbook as a measure of innovation output. However, this ignores the heterogeneity between different patents because most patents have low commercial values [42]. In China, the patents are divided into invention patents, utility model patents, and design patents. Most of the invention patents are a lack of core technologies, and utility model patents and design patents contain low technical content. In order to "seek financial support", some enterprises increase the amount of patent applications and ignore substantive technology innovations [9]. In comparison, this paper selects a more reasonable patent scope and indicator of patent quality. The selection process is as follows:

First, based on Johnstone (2010) [21], we only consider invention patents and exclude those that have a low share of wind power content. Therefore, we use the International Patent Classification (IPC) number F03D to identify wind energy patents. This part of the patent can better reflect the progress of the entire wind power green innovation field [43]. Figure 2 shows the growth of the number of national wind power patents over the years

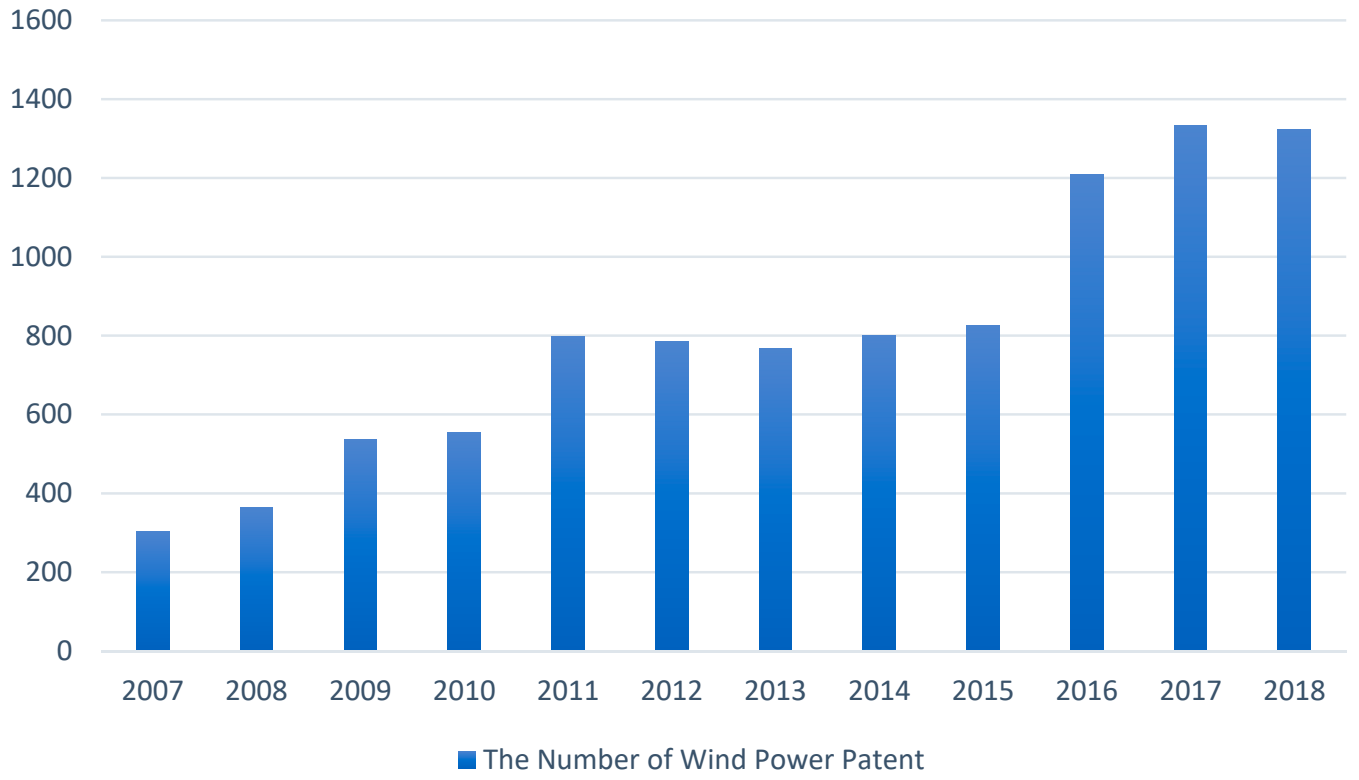

Figure 2. The number of wind power patents.

Secondly, we use the patent quality index rather than patent quantity as the proxy variable of innovation. According to Harhoff et al. (2003), 25\% of valuable patents account for more than $90 \%$ of the total value of patents [44]. To prevent patents with a low value from diluting the output of innovation, this paper uses patent strength to measure the impact of each patent. The data come from the Innography patent database.

Specifically, for each patent, this paper uses the priority date to determine the earliest time the innovation occurs, the location of the patentee as the place where the innovation occurs, while simultaneously recording the strength of the patent. Then, this paper sums up all the patent intensities in each region to calculate the overall patent strength in the region, to measure the wind power innovation performance.

\subsubsection{Demand-Pull Policy Variable}

There are many policy tools that local governments use to adjust and manage the consumptive demand of wind power, including price adjustment, subsidies, low interest loans, tax relief, license issuances, and so on. The new wind power installed capacity is a more reasonable and effective proxy variable to represent the demand-pull policy, which 
can reflect its overall strength at the comprehensive level [43,45,46]. Figure 3 shows the growth of national wind power installed capacity over the years. As for the demandpull policy, we examine the strategic interaction between regions with proximity in the ranking of wind energy resource reserves. When formulating wind power policies in a certain region, the policy is affected by local resource endowment, i.e., wind energy resource reserves, so the region will refer to the policy performance with the same resource conditions. For example, the wind energy resources of Inner Mongolia are similar to Qinghai, Shaanxi, and Xinjiang, so when Qinghai, Shaanxi, and Xinjiang increase policy support, Inner Mongolia will formulate corresponding policies based on their performance.

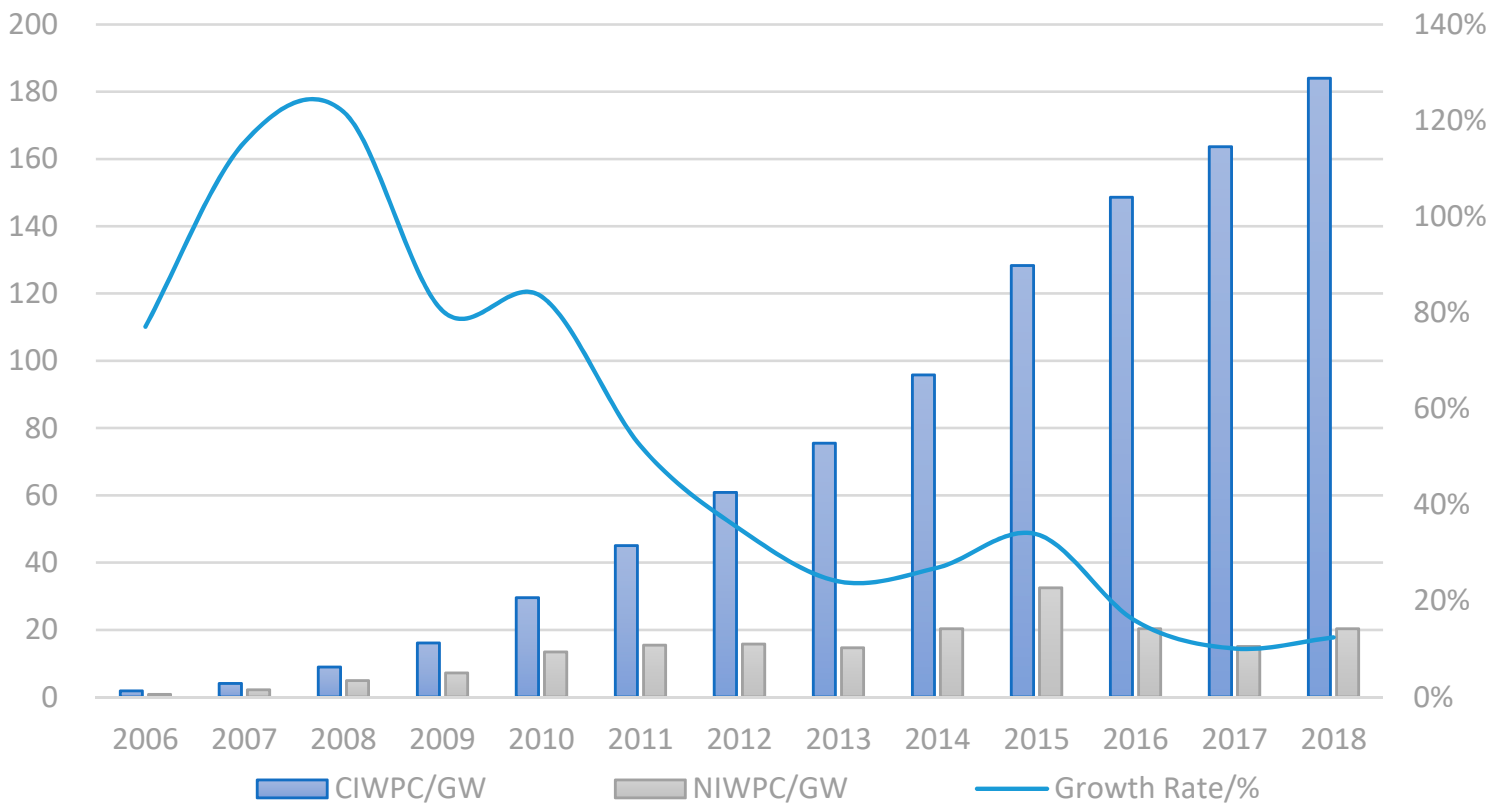

Figure 3. The development of the wind power industry in China. Notes: CIWPC is the abbreviation of Cumulative Installed Wind Power Capacity; NIWPC is the abbreviation of New Installed Wind Power Capacity; GW is the abbreviation of Gigawatt.

\subsubsection{Technology-Push Policy Variable}

We use the R\&D funds input as a proxy variable of the technology-push policy to measure the policy intensity [21,25]. In the study, we did not use the R\&D investment of the wind power industry to measure the intensity of the technology-push policy for three reasons. First, there are no R\&D investment provincial data in the wind power industry. Second, the majority of energy patents with high social values cite and are cited by more non-energy patents [47]. This shows that innovation in wind power needs the joint support of interdisciplinary and multi-field research results. Therefore, this paper believes that $R \& D$ of the whole industry can better measure the technology-push policy. Thirdly, if $R \& D$ in the wind power industry is used, endogenous problems caused by bidirectional causality may also appear. When we use industry-wide R\&D to represent the intensity of the region's technology-push policy, we can mitigate potential endogenous problems. As for the technology-push policy, we examine the strategic interaction between regions with proximity in the ranking of R\&D funds input. Since the 11th Five-Year Plan of China began, $R \& D$ funds input have been included in the assessment indicators of local governments. Therefore, when the local governments formulate a technology-push policy, they will refer to regions with similar R\&D strengths. For example, Jiangsu and Zhejiang are similar in R\&D investment intensity, so when Zhejiang increases R\&D investment, Jiangsu will also implement corresponding policies. 


\subsubsection{Control Variables}

Referring to the design of Fu et al. (2018) [25], this paper considers the power-related factors that affect the innovation of wind power. Between them, power-related factors include power price, thermal power supply rate, and social factors, including population growth rates and regional consumption levels. The details are as follows.

Electricity price (Eprice): This is the average sales price of power grid enterprises. Electricity price is an important signal and regulation intermediary in the power market. At present, the power generation cost of wind power is still higher than that of ordinary thermal power generation. In areas with high electricity prices, this will partially reduce the price disadvantages of wind power and make it more competitive. Therefore, the higher the electricity price, the stronger the incentives for wind power innovation. Additionally, the regression coefficient of electricity prices on innovation is expected to be positive.

Thermal power supply rate (Fire_ElecC): To measure this index, this paper uses the ratio of thermal power generation to total power consumption. During the period of the 12th and 13th Five-Year Plan, the regions with high thermal power supply rates will have greater pressure to transform the energy generation structure. Therefore, the regression coefficient of thermal power supply rates on wind power innovation may be positive.

Population growth rate (PopGrow): This paper uses the ratio of the new population to the total population in the region. The regions with high population growth rates will have a higher demand for power and need more installed capacity, thus creating a potential market for wind power. Therefore, the population growth rate is the important control variable in the model, and the regression coefficient may be positive.

Regional residents' consumption level $(C)$ : In areas with higher consumption levels, residents may have higher expectations and stricter demands on ecological and environmental standards. They also have more willingness to support renewable energy. Therefore, this paper applies the regional residents' consumption level as an important control variable, expecting it to have a positive impact on innovation of wind power.

A summary of the definitions of all the above variables can be found in Table 1.

Table 1. Definition of variable.

\begin{tabular}{|c|c|c|c|}
\hline Variable & Variable Name & Variable Symbol & Variable Definition \\
\hline \multirow[t]{2}{*}{ Innovation output } & Patents strength & patentstr & $\begin{array}{l}\text { The summation of regional patents strength } \\
\text { from Innography patent database }\end{array}$ \\
\hline & Number of patents & patentnum & Regional total number of patents \\
\hline \multirow{2}{*}{ Innovation policy } & Technology-push policy & $\mathrm{RD}$ & $\begin{array}{l}\text { Regional total research and } \\
\text { development investment }\end{array}$ \\
\hline & Demand-pull policy & $\mathrm{dAACz}$ & Regional new wind power installed capacity \\
\hline \multirow{4}{*}{ Control variables } & Electricity price & Eprice & Regional average electricity price \\
\hline & Thermal power supply rate & Fire_ElecC & $\begin{array}{l}\text { Ratio of regional thermal power generation to } \\
\text { regional total power consumption }\end{array}$ \\
\hline & Population growth rate & PopGrow & $\begin{array}{l}\text { Regional new population to the regional } \\
\text { total population }\end{array}$ \\
\hline & $\begin{array}{l}\text { Regional residents' } \\
\text { consumption level }\end{array}$ & C & Regional residents' consumption level \\
\hline \multirow[b]{2}{*}{ Spatial weight } & $\begin{array}{l}\text { Adjacent relationship } \\
\text { in geography }\end{array}$ & $\omega_{i j}^{g e o}$ & $\begin{array}{l}\text { If the region } i \text { and the region } j \text { share a common } \\
\text { geographical boundary, the spatial weight } \\
\text { equals 1, i.e., } \omega_{i j}^{g e o}=1 \text {, otherwise, } \omega_{i j}^{g e o}=0 .\end{array}$ \\
\hline & $\begin{array}{l}\text { Adjacent relationships in } \\
\text { the ranking }\end{array}$ & $\omega_{i j}^{r a n k}$ & $\begin{array}{l}\text { If the region } i \text { and the region } j \text { are next to each } \\
\text { other in the ranking, i.e., } i \text { precedes or follows } j \text {, } \\
\text { the spatial weight equals } 1 \text {, i.e., } \omega_{i j}^{\text {rank }}=1 \text {, } \\
\text { otherwise, } \omega_{i j}^{r a n k}=0 .\end{array}$ \\
\hline
\end{tabular}


The time interval for the policy (stage1 and stage3): The development of the wind power industry in China began in the 1980s. The promulgation of the renewable energy law of China in 2006 and the launch of industrial policies, such as the revitalization and development of the renewable energy industry in 2009, stimulated the explosive growth of the power industry. At the end of 2010, China became the largest country in the world in terms of wind power installed capacity. However, since 2011, the phenomenon of abandoning wind and limiting power has frequently occurred. China's wind power industry began to enter a period of strategic adjustment, and the growth speed of the wind power industry has slowed down. Therefore, the development trend of the wind power industry from 2006-2017 can be divided into three policy ranges: the rapid expansion period in 2006-2010, the policy turbulence period in 2011-2014, and the layout adjustment period in 2015-2017, which can be seen in Figure 3. This paper uses the policy turbulence period (2011-2014) as the benchmark to capture the impact of the development stage and different policy periods, so this paper controls stage 1 and stage 3 . In addition, it uses the fixed-effect model to control unobserved inter-provincial heterogeneity factors.

\subsection{Data Source and Descriptive Statistics}

The 29 provinces of the Chinese mainland are chosen as the study area (Tibet is excluded due to more missing data, and Hainan is not considered due to it not having spatial adjacency with other provinces) from 2006 to 2018. The data comes from the statistical yearbooks of 29 provinces (2007-2019), the China Statistical Yearbook (2007-2019), the China Energy Statistical Yearbook (2007-2019), and the China Power Statistical Yearbook (2007-2019). The electric power data comes from the State Power Regulatory Commission of China, and the patent data comes from the State Intellectual Property Office of China. All variables are reduced to the 2006 price. Table 2 shows the descriptive statistics of the variables.

Table 2. Descriptive statistics.

\begin{tabular}{|c|c|c|c|c|c|c|c|}
\hline Category & Sample Size & Mean & Standard Deviation & Minimum & $\begin{array}{c}25 \% \\
\text { Quantile }\end{array}$ & $\begin{array}{c}75 \% \\
\text { Quantile }\end{array}$ & Maximum \\
\hline patentstr & 348 & 207.118 & 306.58 & 0 & 40 & 262.8 & 2894 \\
\hline patentnum & 348 & 27.589 & 37.351 & 0 & 5.8 & 37 & 247 \\
\hline L.RD & 348 & 331.422 & 417.813 & 3.341 & 68.424 & 428.54 & 2343.63 \\
\hline$W_{g e o} \times L . R D$ & 348 & 319.865 & 291.661 & 13.647 & 120.625 & 430.672 & 1763.20 \\
\hline$W_{\text {rank }}^{\text {sa }} \times$ L.RD & 348 & 325.032 & 356.776 & 11.812 & 81.428 & 415.828 & 1847.14 \\
\hline L.dACCz & 348 & 46.641 & 86.71 & -32 & 0.4 & 57 & 887 \\
\hline$W_{g e o} \times \mathrm{L} . \mathrm{dACCz}$ & 348 & 54.082 & 58.731 & -9 & 9.447 & 79.107 & 391.913 \\
\hline$W_{\text {rank }}{ }^{\prime} \times$ L.dACCz & 348 & 44.915 & 50.96 & -4 & 7 & 65 & 332 \\
\hline L.eprice & 348 & 543.526 & 115.269 & 271.62 & 454.335 & 633.445 & 777.33 \\
\hline L.Fire_ElecC & 348 & 77.662 & 30.942 & 15.582 & 57.646 & 93.821 & 169.755 \\
\hline L.C & 348 & 14.001 & 8.727 & 3.499 & 7.784 & 17.046 & 52.732 \\
\hline L.PopGrow & 348 & 5.201 & 2.624 & -0.6 & 3.223 & 6.86 & 11.78 \\
\hline
\end{tabular}

Notes: L. denotes the 1 period lag of the variable, and the explanatory variables of the model in this paper are all lagged variables.

\section{Results}

\subsection{Spatial Correlation Test}

First, it is necessary to test whether there is any spatial correlation between regional innovation before the regression analysis, especially for spatial autocorrelation. If the spatial correlation exists, a spatial model needs to be established. Otherwise, non-spatial econometric methods need to be used. Spatial autocorrelation is a spatial statistical method that is mainly used to verify the interactions between regions. Between them, the global 
Moran index is a commonly used spatial autocorrelation method (Honma, 2014). Its calculation formula is as follows:

$$
I=\left[n \sum_{i=1}^{n} \sum_{j=1}^{n} \omega_{i j}\left(x_{i}-\bar{x}\right)\left(x_{j}-\bar{x}\right)\right] /\left[\sum_{i=1}^{n} \sum_{j=1}^{n} \omega_{i j} \sum_{i=1}^{n}\left(x_{i}-\bar{x}\right)^{2}\right]
$$

where $x_{i}$ denotes the innovation of the $\mathrm{i}$-th region, $\mathrm{n}$ denotes the number of regions. $\omega_{i j}$ indicates the normalized spatial weight, which is described in Section 3.1. We then define four spatial weight matrices. The first one is based on the neighboring relationship in geography, and its weight is 1 if 2 regions are geographically adjacent, or 0 if not. The second one is also based on the neighboring relationship in geography, but its weight is $1 / \mathrm{d}$, where $\mathrm{d}$ is the road distance between two provinces. The third one is based on the neighboring relationship in the ranking of $R \& D$ funds input, and its weight is 1 if 2 regions are adjacent in ranking, or 0 if not. The $R \& D$ funds inputs of each province are from the China Statistical Yearbook of Science and Technology. The fourth one is based on the neighboring relationship in the ranking of the wind energy resource reserves, and its weight is 1 if 2 regions are adjacent in ranking, or 0 if not. The wind energy resource reserves of each province are from the third Wind Energy Resource Survey of China Meteorological Administration. Table 3 is the result of the spatial autocorrelation test. Column (1)-(4) in Table 3 are the results of the spatial autocorrelation test based on four different spatial weight matrices above, respectively.

Table 3. Moran Index.

\begin{tabular}{ccccc}
\hline & $\mathbf{( 1 )}$ & $\mathbf{( 2 )}$ & $\mathbf{( 3 )}$ & $\mathbf{( 4 )}$ \\
\hline 2007 & $0.2703^{* * *}$ & $0.0285^{* *}$ & $0.5269 * * *$ & 0.0059 \\
2008 & $0.2142^{* *}$ & $0.0362^{* *}$ & $0.4377^{* * *}$ & 0.0267 \\
2009 & $0.0772^{* *}$ & -0.0292 & $0.3498^{* * *}$ & 0.0558 \\
2010 & $0.1627^{* *}$ & -0.007 & $0.4113^{* * *}$ & 0.0121 \\
2011 & $0.1667^{* *}$ & -0.0037 & $0.3439^{* * *}$ & 0.0521 \\
2012 & $0.1030^{*}$ & -0.0272 & $0.1803^{* *}$ & 0.0208 \\
2013 & $0.3679^{* * *}$ & $0.0472^{* *}$ & $0.5665^{* * *}$ & 0.0013 \\
2014 & $0.2033^{* *}$ & $0.0189^{*}$ & $0.4603^{* * *}$ & 0.0036 \\
2015 & $0.1182^{* *}$ & $0.0052^{*}$ & $0.2773^{* * *}$ & 0.0459 \\
2016 & $0.1626^{* * *}$ & $0.0193^{* *}$ & $0.2900^{* * *}$ & 0.056 \\
2017 & $0.1020^{* *}$ & -0.0126 & $0.2658^{* * *}$ & 0.0246 \\
2018 & $0.1399^{*}$ & $0.0307^{* *}$ & $0.3161^{* * *}$ & 0.0805 \\
\hline Notes: Standard errors in parentheses* $p<0.1, * * p<0.05, * * *<0.01$. & &
\end{tabular}

The Moran index in column (1)-(3) of Table 3 shows that there are significant spatial correlations between innovation both in regions with geography proximity and in regions with proximity in the ranking of $R \& D$ funds input, and the correlation in the regions with proximity in the ranking of $R \& D$ funds input is stronger. Furthermore, there is no significant spatial correlation between innovation in the regions with proximity in the ranking of wind energy resource reserves, which can seen in column (4).

\subsection{The Results of the Baseline Model}

According to the difference of the "spatial" relationship between regions, the spatial model can be divided into two types: the spatial lag model (SLM) and the spatial error model (SEM). The key difference between the two models is that the spatial correlation exists in the core explanatory variable or the error term. Therefore, to clarify which model is more appropriate, we should first compare the spatial lag model and the spatial error model. Anselin et al. (1996) suggested comparing the size of the two Lagrangian multipliers (LM-lag and LM-error) [48]. If the two have the same significance level, then it is useful to further compare their robust forms (Robust LM-lag and Robust LM-error) and select the model with the higher significance level. The results of the LM test show that whether 
it is based on the space weight matrix $W_{\text {rank }}$ or the space weight matrix $W_{\text {geo }}$, the spatial error model should be selected. As for the estimation method of the spatial Durbin model, there are two estimation methods: generalized moment estimation (GMM) and maximum likelihood estimation (ML). Leen and Yu (2014) show that if there are multiple spatial weight matrices in the model and $\mathrm{n}$ is greater than T, GMM performs better [7]. Therefore, GMM will be used in this paper. Table 4 shows the estimation results of the model.

Table 4. The regression results.

\begin{tabular}{|c|c|c|c|c|c|c|}
\hline \multirow{3}{*}{ Variables } & \multicolumn{2}{|c|}{ Panel Model } & \multicolumn{2}{|c|}{ GMM: $W^{g e o}$} & \multicolumn{2}{|c|}{ GMM: $W^{r a n k}$} \\
\hline & RE & FE & RE & FE & RE & FE \\
\hline & (1) & (2) & (3) & (4) & (5) & (6) \\
\hline L.RD & $\begin{array}{c}0.2778^{* * *} \\
(0.0000)\end{array}$ & $\begin{array}{c}0.2285^{* * *} \\
(0.0001)\end{array}$ & $\begin{array}{c}0.4294^{* * *} \\
(0.0000)\end{array}$ & $\begin{array}{c}0.3764^{* * *} \\
(0.0000)\end{array}$ & $\begin{array}{c}0.4242^{* * *} \\
(0.0000)\end{array}$ & $\begin{array}{c}0.3831^{* * *} \\
(0.0000)\end{array}$ \\
\hline$W_{\text {geo }} \times$ L.RD & -- & -- & $\begin{array}{c}-0.2869^{* * *} \\
(0.0000)\end{array}$ & $\begin{array}{c}-0.3035^{* * *} \\
(0.0005)\end{array}$ & $\begin{array}{c}-0.2989 * * * \\
(0.0000)\end{array}$ & $\begin{aligned}-0.3185^{* * *} & (0.0002)\end{aligned}$ \\
\hline$W_{\text {rank }} \times L . R D$ & -- & -- & $\begin{array}{c}-0.2880 * * * \\
(0.0000)\end{array}$ & $\begin{array}{c}-0.2617^{* * *} \\
(0.0025)\end{array}$ & $\begin{array}{c}-0.2804^{* * * *} \\
(0.0000)\end{array}$ & $\begin{array}{c}-0.2398^{* * *} \\
(0.0046)\end{array}$ \\
\hline L.dACCz & $\begin{array}{c}0.0819 \\
(0.4803)\end{array}$ & $\begin{array}{c}0.0737 \\
(0.5272)\end{array}$ & $\begin{array}{c}0.0217 \\
(0.8532)\end{array}$ & $\begin{array}{c}0.0405 \\
(0.7174)\end{array}$ & $\begin{array}{c}0.0247 \\
(0.8320)\end{array}$ & $\begin{array}{c}0.0368 \\
(0.7445)\end{array}$ \\
\hline$W_{g e o} \times$ L.dACCz & -- & -- & $\begin{array}{l}-0.0715 \\
(0.7169)\end{array}$ & $\begin{array}{l}-0.0659 \\
(0.7351)\end{array}$ & $\begin{array}{l}-0.0186 \\
(0.9235)\end{array}$ & $\begin{array}{l}-0.0263 \\
(0.8918)\end{array}$ \\
\hline$W_{\text {rank }^{\prime}} \times$ L.dACCz & -- & -- & $\begin{array}{l}-0.2651 \\
(0.2695)\end{array}$ & $\begin{array}{c}-0.3375 \\
(0.1674)\end{array}$ & $\begin{array}{l}-0.2903 \\
(0.2138)\end{array}$ & $\begin{array}{c}-0.324 \\
(0.1817)\end{array}$ \\
\hline L.eprice & $\begin{array}{l}0.4999 * * \\
(0.0110)\end{array}$ & $\begin{array}{l}0.6133^{* *} \\
(0.0113)\end{array}$ & $\begin{array}{l}0.7491^{* * *} \\
(0.0001)\end{array}$ & $\begin{array}{l}1.0929 * * * \\
(0.0000)\end{array}$ & $\begin{array}{l}0.8238^{* * *} \\
(0.0000)\end{array}$ & $\begin{array}{c}1.1473^{* * *} \\
(0.0000)\end{array}$ \\
\hline L.Fire_ElecC & $\begin{array}{c}0.6766 \\
(0.2986)\end{array}$ & $\begin{array}{c}2.9727^{* * *} \\
(0.0037)\end{array}$ & $\begin{array}{l}0.9167 * \\
(0.0936)\end{array}$ & $\begin{array}{c}3.3723 * * * \\
(0.0003)\end{array}$ & $\begin{array}{l}0.9165 * \\
(0.0926)\end{array}$ & $\begin{array}{c}3.3681 * * * \\
(0.0003)\end{array}$ \\
\hline L.C & $\begin{array}{l}9.7577^{* * *} \\
(0.0030)\end{array}$ & $\begin{array}{l}8.9664^{* *} \\
(0.0234)\end{array}$ & $\begin{array}{c}20.1703^{* * *} \\
(0.0000)\end{array}$ & $\begin{array}{c}19.0568^{* * *} \\
(0.0000)\end{array}$ & $\begin{array}{c}19.2103^{* * *} \\
(0.0000)\end{array}$ & $\begin{array}{c}16.7013^{* * *} \\
(0.0000)\end{array}$ \\
\hline L.PopGrow & $\begin{array}{l}-4.9945 \\
(0.5177)\end{array}$ & $\begin{array}{c}-3.78 \\
(0.7623)\end{array}$ & $\begin{array}{c}3.0941 \\
(0.6586)\end{array}$ & $\begin{array}{c}5.8591 \\
(0.6357)\end{array}$ & $\begin{array}{c}3.4254 \\
(0.6138)\end{array}$ & $\begin{array}{c}5.8945 \\
(0.6301)\end{array}$ \\
\hline stage1 & $\begin{array}{c}109.7945^{* * *} \\
(0.0000)\end{array}$ & $\begin{array}{c}100.1457^{* * *} \\
(0.0014)\end{array}$ & $\begin{array}{c}97.0439 * * * \\
(0.0008)\end{array}$ & $\begin{array}{c}105.1436 \text { *** } \\
(0.0007)\end{array}$ & $\begin{array}{c}96.4378^{* * *} \\
(0.0002)\end{array}$ & $\begin{array}{c}99.5896^{* * * *} \\
(0.0004)\end{array}$ \\
\hline stage3 & $\begin{array}{l}16.6231 \\
(0.5516)\end{array}$ & $\begin{array}{l}45.5057 \\
(0.1321)\end{array}$ & $\begin{array}{l}26.5844 \\
(0.3901)\end{array}$ & $\begin{array}{l}59.9025 * \\
(0.0539)\end{array}$ & $\begin{array}{c}36.704 \\
(0.1857)\end{array}$ & $\begin{array}{c}73.579 * * * \\
(0.0100)\end{array}$ \\
\hline (Intercept) & $\begin{array}{c}-373.582 \text { *** } \\
(0.0072)\end{array}$ & & $\begin{array}{c}-561.9486^{* * *} \\
(0.0000)\end{array}$ & & $\begin{array}{c}-588.916 * * * \\
(0.0000)\end{array}$ & \\
\hline Hausman test & & & $\begin{array}{r}45 . \\
(0 .\end{array}$ & & & \\
\hline
\end{tabular}

Notes: Standard errors in parentheses ${ }^{*} p<0.1,{ }^{* *} p<0.05,{ }^{* * *} p<0.01$.

Without considering the spatial spillover effects of the technology-push policy and demand-pull policy, the panel model is used as a benchmark model for analysis. Empirical analysis results are in columns (1) and (2) in Table 4. Then, we use the model to consider the spatial spillover effects of the technology-push policy and the demand-pull policy to analyze further. Columns (3) and (4) in Table 4 are the results from the space error model with the geographic proximity matrix $W_{\text {geo }}$, and the spatial lag of the technology-push policy and the demand-pull policy $W_{\text {geo }} \times L . R D$ and $W_{\text {rank }} \times L . R D$ was incorporated into the model. Similarly, columns (5) and (6) in Table 4 are the result of the space error model with rankings matrix $W_{\text {rank }}$, and the spatial lag of the technology-push policy and the demand-pull policy, $W_{\text {geo }} \times L . R D$ and $W_{\text {rank }} \times L . R D$, was incorporated into the model. In 
addition, columns (1), (3), and (5) show the results of the random effect panel model, and columns (2), (4), and (6) show the results of the fixed-effect panel model. The results of the Hausman test are listed in the last row of Table 4.

As shown in Table 4, for the technology-push policy, we find that local R\&D investment can significantly increase local innovation output, which is significant at the level of $1 \%$. This result is consistent with hypothesis 1 . This positive impact is offset by the negative spillover effect from regions, whether with geography proximity or with proximity in the ranking of R\&D funds input. In other words, the R\&D investment of neighbors has a negative spillover effect on innovation in this region, which is significant at the $1 \%$ level. The above results are consistent with hypothesis 3 . The R\&D investment intensity of each region, as the market signal, influences the flow of R\&D elements (talents, projects, funds, etc.). When other regions increase $R \& D$ investment as a chip for scientific and technological competition, local elements will flow out and inhibit local innovation. In the next section, we will further discuss the spillover effects of competitions around R\&D factors.

For the demand-pull policy represented by the new installed wind power capacity, whether from an inductive effect or a spillover effect, the impact on innovation is not significant, which is inconsistent with hypothesis 2 and hypothesis 4 . However, by observing the data over the years, there is an obvious positive relationship between the newly installed wind power capacity and the patent of the next year. Therefore, we believe that this is not a theoretical error, because the above model misses some factors. Reviewing the theoretical analysis above, we can conclude that market demand expectation is an important component of the spillover effect. Therefore, the correct way to measure market scale and market scope is an important factor that affects the expectation measurement. We will further consider the impact of market sizes in the next section.

For power related variables, we find that the power price has a positive impact on innovation at a significance level of $1 \%$. At present, when the cost of wind power is still higher than that of ordinary thermal power, the increase of regional power prices relatively reduces the disadvantage of wind power costs. This stimulates the growth of the market demand for wind power and improves investments for and promotes the development of the wind power industry, as well as the process of innovation. In addition, the thermal power supply rate has a positive impact on innovation at a $1 \%$ significance level. This indicates that regions dominated by thermal power, whose thermal power generation capacity is greater than the local power demand, must gradually reduce thermal power under the pressure of the power generation structure transformation. This encourages a turn to the clean wind power industry, which also provides an incentive for innovation.

For socioeconomic-related variables, we find that the regional consumption level has a significant positive impact on innovation in all aspects, while the impact of the population growth rate does not pass the significance level. This result supports our conjecture: the higher the consumption level, the higher the residents value environmental protection and are more inclined to choose or support renewable energy, thus affecting the innovation of wind power.

In addition, compared with the 2011-2014 policy turmoil period of abandoning wind power, limiting power, and turning over local approval authority, we found that the other two policy intervals, namely, the rapid expansion period from 2006-2010 and the layout adjustment period from 2015-2017, have less uncertainty around policy. These two policy ranges have a significant positive impact on innovation.

\subsection{Robustness Test}

The effect of R\&D input on innovation output may lag [49,50]. Therefore, we investigate the effect of R\&D on different lag periods, such as a 2-, 3-, and 5-year lag, and the corresponding spatial lagged variables on the output of innovation. We then compare them with the original model with a first-order lag. According to the results in Table 5, we found that the impact of R\&D input on patent output does not have a significant time lag. This result is consistent with other scholars' research [27,51], indicating that the model is 
robust. In addition, we also found that the negative spillover effects from competitors with similar R\&D levels only existed within three years, indicating that when there is strategic interaction between regions, the main reference is the performance of competitors within $1-3$ years.

Table 5. Robust Check.

\begin{tabular}{|c|c|c|c|c|c|c|c|c|}
\hline V i & 1 Period Lag & 2 Period Lag & 3 Period Lag & 5 Period Lag & ML & ML & Patentnum & Patentnum \\
\hline Variabies & $W_{\text {rank }}$ & $W_{\text {rank }}$ & $W_{\text {rank }}$ & $W_{\text {rank }}$ & $W_{g e o}$ & $W_{\text {rank }}$ & $W_{\text {geo }}$ & $W_{\text {rank }}$ \\
\hline L.RD & $\begin{array}{c}0.3663^{* * *} \\
(0.0000)\end{array}$ & $\begin{array}{c}0.3976^{* * *} \\
(0.0000)\end{array}$ & $\begin{array}{c}0.3680 * * * \\
(0.0001)\end{array}$ & $\begin{array}{c}0.6537^{* * *} \\
(0.0000)\end{array}$ & $\begin{array}{c}0.3688^{* * *} \\
(0.0000)\end{array}$ & $\begin{array}{c}0.3661 * * * \\
(0.0000)\end{array}$ & $\begin{array}{c}0.0570 * * * \\
(0.0000)\end{array}$ & $\begin{array}{l}0.057^{* * *} \\
(0.0000)\end{array}$ \\
\hline$W_{\text {geo }} \times L . R D$ & $\begin{array}{c}-0.3180^{* * *} \\
(0.0001)\end{array}$ & $\begin{array}{c}-0.3127^{* * *} \\
(0.0022)\end{array}$ & $\begin{array}{c}-0.2637^{* *} \\
(0.0267)\end{array}$ & $\begin{array}{l}-0.2522 \\
(0.1172)\end{array}$ & $\begin{array}{c}-0.3087^{* * *} \\
(0.0002)\end{array}$ & $\begin{array}{c}-0.3187^{* * *} \\
(0.0001)\end{array}$ & $\begin{array}{c}-0.0200 \text { ** } \\
(0.0197)\end{array}$ & $\begin{array}{c}-0.0205^{* *} \\
(0.0162)\end{array}$ \\
\hline $\begin{array}{c}W_{\text {rank }} \times \\
\text { L.RD }\end{array}$ & $\begin{array}{c}-0.2333^{* * *} \\
(0.0058)\end{array}$ & $\begin{array}{c}-0.2305^{* *} \\
(0.0211)\end{array}$ & $\begin{array}{l}-0.1472 \\
(0.2004)\end{array}$ & $\begin{array}{l}-0.1477 \\
(0.3540)\end{array}$ & $\begin{array}{c}-0.2464^{* * *} \\
(0.0030)\end{array}$ & $\begin{array}{c}-0.2325^{* * *} \\
(0.0051)\end{array}$ & $\begin{array}{c}-0.0229 * * * \\
(0.0065)\end{array}$ & $\begin{array}{c}-0.0226^{* * * *} \\
(0.0071)\end{array}$ \\
\hline L.dACCz & $\begin{array}{l}-0.0279 \\
(0.7981)\end{array}$ & $\begin{array}{c}0.0060 \\
(0.9566)\end{array}$ & $\begin{array}{c}0.0183 \\
(0.8727)\end{array}$ & $\begin{array}{c}0.0113 \\
(0.9243)\end{array}$ & $\begin{array}{l}-0.0020 \\
(0.9845)\end{array}$ & $\begin{array}{l}-0.0296 \\
(0.7822)\end{array}$ & $\begin{array}{c}0.0022 \\
(0.8393)\end{array}$ & $\begin{array}{c}0.0012 \\
(0.9117)\end{array}$ \\
\hline $\begin{array}{c}W_{\text {total }} \times \\
\text { L.dACC }\end{array}$ & $\begin{array}{l}1.0884^{* *} \\
(0.0175)\end{array}$ & $\begin{array}{l}1.0330^{* *} \\
(0.0310)\end{array}$ & $\begin{array}{l}1.0491 * * \\
(0.0317)\end{array}$ & $\begin{array}{l}0.9510^{*} \\
(0.0533)\end{array}$ & $\begin{array}{l}1.1296 * * \\
(0.0172)\end{array}$ & $\begin{array}{l}1.086^{* *} \\
(0.0155)\end{array}$ & $\begin{array}{c}0.0080 \\
(0.8669)\end{array}$ & $\begin{array}{c}0.0084 \\
(0.8588)\end{array}$ \\
\hline $\begin{array}{l}W_{\text {rank }^{\prime}} \times \\
\text { L.dACC }\end{array}$ & $\begin{array}{c}-0.4999 * * \\
(0.0409)\end{array}$ & $\begin{array}{c}-0.4808^{*} \\
(0.0605)\end{array}$ & $\begin{array}{l}-0.4431 \text { * } \\
(0.0976)\end{array}$ & $\begin{array}{l}-0.3440 \\
(0.2266)\end{array}$ & $\begin{array}{c}-0.5737 \text { ** } \\
(0.0170)\end{array}$ & $\begin{array}{c}-0.4951 \text { ** } \\
(0.0392)\end{array}$ & $\begin{array}{l}-0.0370 \\
(0.1281)\end{array}$ & $\begin{array}{l}-0.0357 \\
(0.1431)\end{array}$ \\
\hline L.eprice & $\begin{array}{c}0.9044^{* * *} \\
(0.0006)\end{array}$ & $\begin{array}{c}0.9011 \text { *** } \\
(0.0017)\end{array}$ & $\begin{array}{c}0.8154^{* * * *} \\
(0.0074)\end{array}$ & $\begin{array}{l}0.7192 * * \\
(0.0280)\end{array}$ & $\begin{array}{c}0.9104 * * * \\
(0.0006)\end{array}$ & $\begin{array}{l}0.904 * * * \\
(0.0005)\end{array}$ & $\begin{array}{c}0.0785^{* * *} \\
(0.0038)\end{array}$ & $\begin{array}{c}0.0774^{* * *} \\
(0.0040)\end{array}$ \\
\hline L.Fire_ElecC & $\begin{array}{c}3.2835^{* * *} \\
(0.0005)\end{array}$ & $\begin{array}{c}3.1624^{* * *} \\
(0.0021)\end{array}$ & $\begin{array}{l}2.8073^{* *} \\
(0.0131)\end{array}$ & $\begin{array}{l}2.6369^{*} \\
(0.0744)\end{array}$ & $\begin{array}{c}3.1967^{* * *} \\
(0.0006)\end{array}$ & $\begin{array}{c}3.2871^{* * *} \\
(0.0004)\end{array}$ & $\begin{array}{c}0.2275 * * \\
(0.0161)\end{array}$ & $\begin{array}{l}0.2277^{* *} \\
(0.0163)\end{array}$ \\
\hline L.C & $\begin{array}{c}16.3731^{* * *} \\
(0.0000)\end{array}$ & $\begin{array}{c}14.6677^{* * * *} \\
(0.0009)\end{array}$ & $\begin{array}{c}11.3742 \text { ** } \\
(0.0158)\end{array}$ & $\begin{array}{l}-0.4517 \\
(0.9354)\end{array}$ & $\begin{array}{c}17.3203 * * * \\
(0.0000)\end{array}$ & $\begin{array}{c}16.3076^{* * *} \\
(0.0000)\end{array}$ & $\begin{array}{c}1.7376^{* * *} \\
(0.0000)\end{array}$ & $\begin{array}{c}1.7184^{* * *} \\
(0.0000)\end{array}$ \\
\hline L.PopGrow & $\begin{array}{l}11.2537 \\
(0.3537)\end{array}$ & $\begin{array}{l}-0.6143 \\
(0.9627)\end{array}$ & $\begin{array}{l}-4.5278 \\
(0.7427)\end{array}$ & $\begin{array}{c}-18.1948 \\
(0.2466)\end{array}$ & $\begin{array}{l}10.6928 \\
(0.3762)\end{array}$ & $\begin{array}{l}11.2907 \\
(0.3432)\end{array}$ & $\begin{array}{c}0.0778 \\
(0.9492)\end{array}$ & $\begin{array}{c}0.0629 \\
(0.9587)\end{array}$ \\
\hline stage1 & $\begin{array}{c}106.3246^{* * *} \\
(0.0000)\end{array}$ & $\begin{array}{c}105.8031 \text { *** } \\
(0.0002)\end{array}$ & $\begin{array}{c}97.6224^{* * *} \\
(0.0007)\end{array}$ & $\begin{array}{c}72.4685^{* *} \\
(0.0180)\end{array}$ & $\begin{array}{c}112.6882^{* * *} \\
(0.0000)\end{array}$ & $\begin{array}{c}105.8946^{* * *} \\
(0.0000)\end{array}$ & $\begin{array}{c}10.3397^{* * *} \\
(0.0003)\end{array}$ & $\begin{array}{c}10.1168 \text { *** } \\
(0.0003)\end{array}$ \\
\hline stage3 & $\begin{array}{c}54.9627^{*} \\
(0.0560)\end{array}$ & $\begin{array}{c}61.1998^{* *} \\
(0.0467)\end{array}$ & $\begin{array}{l}61.6752 * \\
(0.0543)\end{array}$ & $\begin{array}{c}86.2064^{* *} \\
(0.0117)\end{array}$ & $\begin{array}{l}49.7964 * \\
(0.0938)\end{array}$ & $\begin{array}{c}55.3112 * * \\
(0.0495)\end{array}$ & $\begin{array}{l}6.0229 * * \\
(0.0459)\end{array}$ & $\begin{array}{l}6.1305^{* *} \\
(0.0386)\end{array}$ \\
\hline
\end{tabular}

Notes: Standard errors in parentheses ${ }^{*} p<0.1,{ }^{* *} p<0.05,{ }^{* * *} p<0.01$.

The number of patents, but not patent strength or quality, was used as a proxy variable of innovation, and repeats the previous empirical analysis. We can find that the inductive and spillover effects of the demand-pull policy on innovation are still positive, but not significant. The possible explanation is that the demand-pull policy releases expectations of a bigger market, and enterprises are more inclined to let R\&D personnel focus on improving the quality of patents and improve the quality of products to maintain long-term competitiveness, but not the number of patents.

In addition, another commonly used estimation method, known as maximum likelihood estimation, was used in the spatial model to study the aforementioned problems, and we found no significant change in the results.

\section{Further Discussion of the Strategic Interaction Mode between Local Governments}

\subsection{The Strategic Interaction Mode of the Demand-Pull Policy between Local Governments}

Compared with the research based on a country level, in research based on domestic regions, local regions are less affected by geographical and policy isolation, and the market that can be reached in a certain region may not only be the local market, but also the external market. However, the impact of local markets is not significant, and we think this is due to its small market scale. Innovators focus on changes in demand across the country, not in the local market, unless they are large enough. Therefore, by changing the weight matrix, we consider two indicators that can measure the strength of the national demand-pull policy outside the region: one is the inverse distance weight matrix (the farther the distance is, the 
more factors, such as transportation and information, may weaken this spillover effect); another is the equal-weight matrix (the market position of each region is equal), and both are standardized.

The results are shown in Table 6. When the measurement range of the demand-pull policy is extended to the whole country and the equal weight matrix is used, that is, column (3) in Table 6, this shows a positive spillover effect on innovation in the region. This is significant at the $1 \%$ level, while the result in column (2) using the inverse distance weight matrix is not significant. It shows that the status of different regions is similar. In addition, we also find that after adjusting the spatial weight, the demand-pull policy from the neighboring endowment ranking shows a significant negative effect. The above results verify the correctness of the research hypothesis $\mathrm{H} 2 \mathrm{~b}$ : the growth expectation of the national total demand is an important part of the spillover effect of the demand-pull policy. When the demand-pull policy is strengthened across the country, the expected growth of the aggregated demand will induce firms to innovate. However, the competition in regions with proximity in the ranking of wind energy resource reserve will stifle innovation.

Table 6. Further analysis for the mechanism and interaction mode.

\begin{tabular}{|c|c|c|c|c|c|c|}
\hline \multirow{2}{*}{ Variables } & \multicolumn{3}{|c|}{ Demand-Pull Policy } & \multicolumn{3}{|c|}{ Regional Heterogeneity } \\
\hline & (1) & (2) & (3) & (4) & (5) & (6) \\
\hline$L . R D$ & $\begin{array}{c}0.3831^{* * *} \\
(0.0000)\end{array}$ & $\begin{array}{c}0.3733^{* * *} \\
(0.0000)\end{array}$ & $\begin{array}{c}0.3663 * * * \\
(0.0000)\end{array}$ & $\begin{array}{c}0.4024^{* * *} \\
(0.0000)\end{array}$ & $\begin{array}{c}0.3395^{* * *} \\
(0.0000)\end{array}$ & $\begin{array}{c}0.3738^{* * *} \\
(0.0000)\end{array}$ \\
\hline$W_{g e o} \times L . R D$ & $\begin{array}{l}-0.3185^{* * *} \\
(0.0002)\end{array}$ & $\begin{array}{c}-0.3310 * * * \\
(0.0000)\end{array}$ & $\begin{array}{l}-0.3180 * * * \\
(0.0001)\end{array}$ & $\begin{array}{c}-0.3617^{* * *} \\
(0.0000)\end{array}$ & $\begin{array}{l}-0.3807 * * * \\
(0.0009)\end{array}$ & $\begin{array}{l}-0.3999 * * * \\
(0.0004)\end{array}$ \\
\hline$W_{\text {rank }} \times L . R D$ & $\begin{array}{c}-0.2398 * * * \\
(0.0046)\end{array}$ & $\begin{array}{c}-0.2239 * * * \\
(0.0085)\end{array}$ & $\begin{array}{c}-0.2333 * * * \\
(0.0058)\end{array}$ & $\begin{array}{c}-0.2511^{* * *} \\
(0.0023)\end{array}$ & $\begin{array}{c}-0.8237^{* * *} \\
(0.0009)\end{array}$ & $\begin{array}{c}-0.9271^{* * *} \\
(0.0001)\end{array}$ \\
\hline L.dACCz & $\begin{array}{c}0.0368 \\
(0.7445)\end{array}$ & $\begin{array}{l}-0.0191 \\
(0.8633)\end{array}$ & $\begin{array}{l}-0.0279 \\
(0.7981)\end{array}$ & $\begin{array}{c}0.0135 \\
(0.8988)\end{array}$ & $\begin{array}{l}-0.0458 \\
(0.6697)\end{array}$ & $\begin{array}{c}0.0001 \\
(0.9986)\end{array}$ \\
\hline$W_{g e o} \times$ L.dACCz & $\begin{array}{l}-0.0263 \\
(0.8918)\end{array}$ & & & & & \\
\hline$W_{d i s} \times \mathrm{L} . \mathrm{dACC} z$ & & $\begin{array}{c}0.7245 \\
(0.1714)\end{array}$ & & & & \\
\hline$W_{\text {total }} \times$ L.dACCz & & & $\begin{array}{l}1.0884 * * \\
(0.0175)\end{array}$ & $\begin{array}{c}2.7381^{* * *} \\
(0.0000)\end{array}$ & $\begin{array}{l}1.0285 * * \\
(0.0192)\end{array}$ & $\begin{array}{c}2.7493^{* * * *} \\
(0.0000)\end{array}$ \\
\hline $\mathrm{Dr} \times W_{g e o} \times$ L.RD & & & & & $\begin{array}{c}0.1581 \\
(0.2611)\end{array}$ & $\begin{array}{c}0.1241 \\
(0.3643)\end{array}$ \\
\hline $\mathrm{Dr} \times W_{\text {rank }} \times$ L.RD & & & & & $\begin{array}{l}0.4633 * \\
(0.0552)\end{array}$ & $\begin{array}{l}0.5535^{* *} \\
(0.0189)\end{array}$ \\
\hline $\mathrm{Dw} \times W_{\text {total }} \times \mathrm{L} \cdot \mathrm{dACC} z$ & & & & $\begin{array}{c}-3.1928 * * * \\
(0.0000)\end{array}$ & & $\begin{array}{c}-3.2764^{* * *} \\
(0.0000)\end{array}$ \\
\hline $\mathrm{Dw} \times W_{r a n k^{\prime}} \times \mathrm{L} \cdot \mathrm{dACC} z$ & & & & $\begin{array}{c}2.5173^{* * *} \\
(0.0000)\end{array}$ & & $\begin{array}{c}2.6790 * * * \\
(0.0000)\end{array}$ \\
\hline$W_{\text {rank }} \times$ L.dACCz & $\begin{array}{c}-0.324 \\
(0.1817)\end{array}$ & $\begin{array}{c}-0.4521 * \\
(0.0841)\end{array}$ & $\begin{array}{c}-0.4999 * * \\
(0.0409)\end{array}$ & $\begin{array}{c}-2.4305^{* * *} \\
(0.0000)\end{array}$ & $\begin{array}{c}-0.4901 \text { ** } \\
(0.0431)\end{array}$ & $\begin{array}{c}-2.5806^{* * *} \\
(0.0000)\end{array}$ \\
\hline L.eprice & $\begin{array}{l}1.1473^{* * *} \\
(0.0000)\end{array}$ & $\begin{array}{l}1.0466^{* * *} \\
(0.0000)\end{array}$ & $\begin{array}{l}0.9044^{* * *} \\
(0.0006)\end{array}$ & $\begin{array}{l}1.0275^{* * *} \\
(0.0000)\end{array}$ & $\begin{array}{l}1.1278^{* * *} \\
(0.0000)\end{array}$ & $\begin{array}{l}1.2657^{* * *} \\
(0.0000)\end{array}$ \\
\hline L.Fire_ElecC & $\begin{array}{c}3.3681 * * * \\
(0.0003)\end{array}$ & $\begin{array}{c}3.4059 * * * \\
(0.0003)\end{array}$ & $\begin{array}{c}3.2835 * * * \\
(0.0005)\end{array}$ & $\begin{array}{c}2.9441^{* * *} \\
(0.0015)\end{array}$ & $\begin{array}{c}3.1563^{* * *} \\
(0.0008)\end{array}$ & $\begin{array}{c}2.8098^{* * *} \\
(0.0022)\end{array}$ \\
\hline L.C & $\begin{array}{l}16.7013^{* * *} \\
(0.0000)\end{array}$ & $\begin{array}{l}16.1156^{* * *} \\
(0.0000)\end{array}$ & $\begin{array}{l}16.3731^{* * *} \\
(0.0000)\end{array}$ & $\begin{array}{l}12.9914^{* * *} \\
(0.0014)\end{array}$ & $\begin{array}{l}17.0880 * * * \\
(0.0000)\end{array}$ & $\begin{array}{l}13.759^{* * *} \\
(0.0005)\end{array}$ \\
\hline
\end{tabular}


Table 6. Cont.

\begin{tabular}{|c|c|c|c|c|c|c|}
\hline \multirow{2}{*}{ Variables } & \multicolumn{3}{|c|}{ Demand-Pull Policy } & \multicolumn{3}{|c|}{ Regional Heterogeneity } \\
\hline & (1) & (2) & (3) & (4) & (5) & (6) \\
\hline L.PopGrow & $\begin{array}{c}5.8945 \\
(0.6301)\end{array}$ & $\begin{array}{c}6.4087 \\
(0.5933)\end{array}$ & $\begin{array}{l}11.2537 \\
(0.3537)\end{array}$ & $\begin{array}{l}13.1630 \\
(0.2659)\end{array}$ & $\begin{array}{l}12.6355 \\
(0.2885)\end{array}$ & $\begin{array}{c}13.966 \\
(0.2281)\end{array}$ \\
\hline stage1 & $\begin{array}{c}99.5896^{* * *} \\
(0.0004)\end{array}$ & $\begin{array}{c}105.4991^{* * *} \\
(0.0001)\end{array}$ & $\begin{array}{c}106.3246^{* * *} \\
(0.0000)\end{array}$ & $\begin{array}{c}87.7371^{* * *} \\
(0.0015)\end{array}$ & $\begin{array}{c}78.1971 * * * \\
(0.0034)\end{array}$ & $\begin{array}{l}58.312 * * \\
(0.0284)\end{array}$ \\
\hline stage3 & $\begin{array}{c}73.579 * * * \\
(0.0100)\end{array}$ & $\begin{array}{c}68.2274^{* *} \\
(0.0151)\end{array}$ & $\begin{array}{c}54.9627^{*} \\
(0.0560)\end{array}$ & $\begin{array}{c}96.8565^{* * *} \\
(0.0011)\end{array}$ & $\begin{array}{c}90.2725^{* * *} \\
(0.0019)\end{array}$ & $\begin{array}{c}135.36^{* * *} \\
(0.0000)\end{array}$ \\
\hline
\end{tabular}

Notes: $\mathrm{Dr}=1$ represents the regions with high R\&D intensity, which are the top $40 \%$ of regions in the ranking of $R \& D$ funds input; $\mathrm{Dr}=0$ represents the regions with low $R \& D$ intensity. $\mathrm{Dw}=1$ represents the regions with abundant wind energy resource reserves, which are the top $40 \%$ of regions in the ranking of wind energy resource reserves; $\mathrm{Dw}=0$ represents the regions with scarce wind energy resource reserves. Standard errors in parentheses ${ }^{*} p<0.1,{ }^{* *} p<0.05,{ }^{* * *} p<0.01$.

\subsection{Heterogeneity Analysis}

Due to China's vast territory, the endowments of different provinces are quite different, and the formation of strategic interactions between different local governments is affected by the differences in their characteristics. To further explore the impact of regional heterogeneity on the mechanisms and interaction modes studied above, we distinguished the two heterogeneities of resource endowment in wind energy resource reserves and $R \& D$ funds input and introduced them into the model through dummy variables. The results are shown in columns (4)-(6) in Table 6. For convenience, we organize the above data into Table 7.

Table 7. Heterogeneity analysis.

\begin{tabular}{|c|c|c|c|c|c|}
\hline \multirow{2}{*}{$\begin{array}{l}\text { Demand-Pull } \\
\text { Policies }\end{array}$} & Geography & Ranking & \multirow{2}{*}{$\begin{array}{c}\text { Technology-Push } \\
\text { Policy }\end{array}$} & \multirow{2}{*}{$\begin{array}{c}\text { Geography } \\
W_{g e o} \times L . R D\end{array}$} & \multirow{2}{*}{$\begin{array}{c}\text { Ranking } \\
W_{\text {rank }} \times L . R D\end{array}$} \\
\hline & $W_{\text {total }} \times$ L.dACCz & $W_{r^{\prime a n k}} \times$ L.dACCz & & & \\
\hline $\begin{array}{l}\text { The regions with } \\
\text { scarce wind energy } \\
\text { resources }\end{array}$ & $2.7493^{* * *}$ & $-2.5806^{* * *}$ & $\begin{array}{l}\text { The regions with } \\
\text { low R\&D intensity }\end{array}$ & $-0.3999 * * *$ & $-0.9271^{* * *}$ \\
\hline $\begin{array}{l}\text { The regions with } \\
\text { abundant wind } \\
\text { energy resources }\end{array}$ & $-0.5271^{* * *}$ & $0.0984^{* * *}$ & $\begin{array}{l}\text { The regions with } \\
\text { high R\&D intensity }\end{array}$ & -0.2758 & $-0.3736^{* * *}$ \\
\hline $\begin{array}{l}\text { Gaps between } \\
\text { groups }\end{array}$ & $-3.2764^{* * *}$ & $2.679 * * *$ & $\begin{array}{l}\text { Gaps between } \\
\text { groups }\end{array}$ & 0.1241 & $0.5535^{* * *}$ \\
\hline
\end{tabular}

Notes: The regions with high R\&D intensity are the top $40 \%$ of regions in the ranking of R\&D funds input. The regions with abundant wind energy are the top $40 \%$ of regions in the ranking of wind energy reserves. ${ }^{* * *} p<0.01$.

Compared with regions with abundant wind energy resources, we find that regions with scarce wind energy resources suffer more significant spillover effects. That is, innovation in these regions is more vulnerable to the positive spillover effects of the overall market pull policy and the negative spillover effects of the market pull policy ranking similar to the opponent. This may be because these regions lack inherent resource endowment advantages, and only when the overall market demand of the outside world changes significantly can they be encouraged to perform innovation. However, the influence of this incentive is easily offset by the negative effect of competitors. On the contrary, innovation in regions with abundant wind energy resources is hardly affected by the market pull policy in regions with similar wind energy resources. Such resource advantages can make people pay attention to the local market and keep the innovation process relatively independent. Although it is still slightly negatively affected by the overall market, this may be caused by the competition between the local market and the overall market.

In addition, the regions with low R\&D intensity are significantly affected by the negative spillover effect of competitors with proximity in the ranking of R\&D funds input. 
Relatively speaking, the negative spillover effect for regions with high R\&D intensity is significantly weakened. The above phenomenon is in line with our conjecture: the talent flow caused by the competition between scientific and technological highlands leads to the loss of knowledge in one place and the growth of knowledge in another place. However, the competition between R\&D highlands offsets the negative effect of brain drain by promoting the attention of various regions to scientific research environments, systems, and efficiencies, or through the knowledge spillover effects brought on by talent flow. However, for ordinary areas with no outstanding R\&D foundation or weak talent attraction, the competition is more intense, which mainly causes negative effects.

\section{Conclusions and Policy Implications}

Green innovation and its diffusion are essential methods for dealing with global climate change and energy crises [52]. Green innovation of the renewable energy industry is not only a question of sustainable energy development and changing energy consumption structures, but it is also an important driving force for approaching the "carbon neutral" target [53]. Through the low-carbon energy transition, China will contribute more than $25 \%$ of global emission reduction [54].

As one of the most important types of new energy, wind energy is particularly important for green development. Thus, this paper takes the wind energy industry as a research case, empirically studies the inductive and spatial spillover effects of the technology-push policy as well as the demand-pull policy on innovation in the wind power industry. We find that the local technology-push policy has a significant positive effect on wind energy innovation, but it is also affected by the negative spillover effect of the technology-push policy from the regions with geographical proximity and the regions with proximity in the ranking of R\&D funds input. In addition, inter-regional factor competition has a greater negative effect on the regions with lower rankings of R\&D support intensity than those with higher rankings. As for the demand-pull policy, we found that there are no significant effects on the wind power industry in terms of innovation for both the demand-pull policy of local and neighboring regions, geographically. Yet, the demand expansion at the national level, i.e., the sum of the intensity of all regions' demand-pull policies, has a positive effect on wind energy innovation. The main reason is that innovation activities are more influenced by large market demand changes than by small local market demand changes. As for the regions with similar resource endowments, the demand-pull policy has a significant negative spillover effect on the innovation of neighboring regions. In addition, we find that regions with abundant wind energy resources are less affected by the overall market or competitors, while regions with scarce wind energy resources are more affected by the spillovers from neighboring regions. It should be noted that the above empirical findings are mainly aimed at the wind power industry. To expand to other new energy fields, although the theoretical mechanism of innovation policy should be similar, further testing is still needed.

In recent years, green and sustainable development has become an important component of global economic development. Countries are actively promoting green transformation, and enhancing green innovation capacity is the key to achieving green transformation. Local governments that want to improve the level of green innovation in their region should pay attention to the combination of technology-push policy and demand-pull policy and consider the impact of policy changes on their neighbors, whether geographically or in rankings of a certain aspect, and at the national level in terms of their green development goals. Additionally, when the central government makes industry development plans, it should fully consider the heterogeneity between different regions and the spillover effects caused by competitions between local governments to form a benign competition mechanism for green development between regions. These suggestions are helpful in promoting global green transformation.

This paper also has some shortcomings: (1) This paper takes the innovation in China's wind power industry as the research object and reaches a conclusion. However, it remains 
to be seen whether this conclusion can be extended to the whole renewable energy industry or even to other industries carrying out green innovation. (2) Limited to the availability of data, this paper is based on China's provincial data, and whether this conclusion can also be obtained at the city level needs to be studied further. In addition, this paper discusses the impact of innovation policies and strategic interactions between governments on green innovation from the macro level, without examining the response of micro enterprises. Future research on the impact of innovation policies on the green innovation of enterprises is helpful to further clarify the internal mechanism. (3) This article does not discuss the differences between the impact of innovation policies and the strategic interaction between the government in terms of green innovation for developing countries in different development phases. We know that the market environment for developing counties is constantly changing and the government's optimal innovation policy intensity is different in different periods. Thus, the optimal intensity of an innovation policy in different development phases is worthy of more focused research, which is helpful insofar as allocating innovation resources and reducing wasted resources, thus further accelerating the green transformation of developing countries.

Author Contributions: Conceptualization, H.S. and C.L.; Formal analysis, H.S.; Methodology, H.S.; Project administration, C.L.; Writing-original draft, H.S.; Writing-review \& editing, X.D. and L.Z. All authors have read and agreed to the published version of the manuscript.

Funding: This research received no external funding.

Data Availability Statement: Data was obtained from China official national statistical database.

Conflicts of Interest: The authors declare no conflict of interest.

\section{References}

1. $\mathrm{Du}, \mathrm{K} . ; \mathrm{Li}, \mathrm{J}$. Towards a green world: How do green technology innovations affect total-factor carbon productivity. Energy Policy 2019, 131, 240-250. [CrossRef]

2. Shao, X.; Zhong, Y.; Liu, W.; Li, R.Y.M. Modeling the effect of green technology innovation and renewable energy on carbon neutrality in N-11 countries? Evidence from advance panel estimations. J. Environ. Manag. 2021, 296, 113189. [CrossRef] [PubMed]

3. Franceschini, S.; Faria, L.G.D.; Jurowetzki, R. Unveiling scientific communities about sustainability and innovation. A bibliometric journey around sustainable terms. J. Clean. Prod. 2016, 127, 72-83. [CrossRef]

4. Rennings, K. Redefining innovation-Eco-innovation research and the contribution from ecological economics. Ecol. Econ. 2000, 32, 319-332. [CrossRef]

5. Roh, T.; Lee, K.; Yang, J.Y. How do intellectual property rights and government support drive a firm's green innovation? The mediating role of open innovation. J. Clean. Prod. 2021, 317, 128422. [CrossRef]

6. González, P.D.R. The empirical analysis of the determinants for environmental technological change: A research agenda. Ecol. Econ. 2009, 68, 861-878. [CrossRef]

7. Yu, J; Zhou, L.-A.; Zhu, G. Strategic interaction in political competition: Evidence from spatial effects across Chinese cities. Reg. Sci. Urban Econ. 2016, 57, 23-37. [CrossRef]

8. Wang, B.B.; Qi, S.Z. The effect of market-oriented and command-and-control policy tools on emissions reduction innovation: An empirical analysis based on China's industrial patents data. China Ind. Econ. 2016, 6, 91-108. [CrossRef]

9. Li, W.; Zheng, M. Is it Substantive Innovation or Strategic Innovation?-Impact of Macroeconomic Policies on Micro-enterprises' Innovation. Econ. Res. J. 2016, 4, 60-73.

10. Li, H.; Zhou, L.-A. Political turnover and economic performance: The incentive role of personnel control in China. J. Public Econ. 2004, 89, 1743-1762. [CrossRef]

11. Besley, T.; Case, A. Incumbent Behavior: Vote Seeking, Tax Setting and Yardstick Competition; National Bureau of Economic Research: Cambridge, MA, USA, 1992. [CrossRef]

12. Salmon, P. Decentralisation as an incentive scheme. Oxf. Rev. Econ. Policy 1987, 3, 24-43. [CrossRef]

13. Dosi, G. Technological paradigms and technological trajectories: A suggested interpretation of the determinants and directions of technical change. Res. Policy 1993, 22, 102-103. [CrossRef]

14. Hoppmann, J.; Wu, G.; Johnson, J. The impact of demand-pull and technology-push policies on firms' knowledge search. Technol. Forecast. Soc. Chang. 2021, 170, 120863. [CrossRef]

15. Horbach, J.; Rammer, C.; Rennings, K. Determinants of eco-innovations by type of environmental impact-The role of regulatory push/pull, technology push and market pull. Ecol. Econ. 2012, 78, 112-122. [CrossRef]

16. Bush, V. The Endless Frontier, Report to the President on a Program for Postwar Scientific Research; Office of Scientific and Development: Washington, DC, USA, 1945. 
17. Schmookler, J. Invention and Economic Growth; Harvard University Press: Cambridge, MA, USA, 1966. [CrossRef]

18. Mowery, D.; Rosenberg, N. The influence of market demand upon innovation: A critical review of some recent empirical studies. Res. Policy 1979, 8, 102-153. [CrossRef]

19. Pavitt, K. Sectoral patterns of technical change: Towards a taxonomy and a theory. Res. Policy 1984, 13, 343-373. [CrossRef]

20. Horbach, J. Determinants of environmental innovation-New evidence from German panel data sources. Res. Policy 2008, 37, 163-173. [CrossRef]

21. Johnstone, N.; Haščič, I.; Popp, D. Renewable Energy Policies and Technological Innovation: Evidence Based on Patent Counts. Environ. Resour. Econ. 2009, 45, 133-155. [CrossRef]

22. Kim, K.; Heo, E.; Kim, Y. Dynamic Policy Impacts on a Technological-Change System of Renewable Energy: An Empirical Analysis. Environ. Resour. Econ. 2015, 66, 205-236. [CrossRef]

23. Watanabe, C.; Wakabayashi, K.; Miyazawa, T. Industrial dynamism and the creation of a "virtuous cycle" between R\&D, market growth and price reduction: The case of photovoltaic power generation (PV) development in Japan. Technovation 2000, 20, 299-312. [CrossRef]

24. Cleff, T.; Rennings, K. Determinants of environmental product and process innovation. Eur. Environ. 1999, 9, 191-201. [CrossRef]

25. Fu, W.; Li, C.; Ondrich, J.; Popp, D. Technological Spillover Effects of State Renewable Energy Policy: Evidence from Patent Counts; National Bureau of Economic Research: Cambridge, MA, USA, 2018. [CrossRef]

26. Popp, D. Induced Innovation and Energy Prices. Am. Econ. Rev. 2002, 92, 160-180. [CrossRef]

27. Brunnermeier, S.B.; Cohen, M.A. Determinants of environmental innovation in US manufacturing industries. J. Environ. Econ. Manag. 2003, 45, 278-293. [CrossRef]

28. Sarzynski, A.; Larrieu, J.; Shrimali, G. The impact of state financial incentives on market deployment of solar technology. Energy Policy 2012, 46, 550-557. [CrossRef]

29. Wilson, J.D. Theories of Tax Competition. Natl. Tax J. 1999, 52, 269-304. [CrossRef]

30. Brueckner, J.K. Welfare Reform and the Race to the Bottom: Theory and Evidence. South. Econ. J. 2000, 66, 505-525. [CrossRef]

31. Wildasin, D.E. Income Redistribution in a Common Labor Market. Am. Econ. Rev. 1991, 81, 757-774.

32. Almeida, P.; Kogut, B. Localization of Knowledge and the Mobility of Engineers in Regional Networks. Manag. Sci. 1999, 45, 905-917. [CrossRef]

33. Los, B.; Verspagen, B. R\&D spillovers and productivity: Evidence from U.S. manufacturing microdata. Empir. Econ. 2000, 25, 127-148. [CrossRef]

34. Ju, J.; Lin, J.Y.; Wang, Y. Endowment structures, industrial dynamics, and economic growth. J. Monet. Econ. 2015, 76, 244-263. [CrossRef]

35. Chen, H.; Liu, S.; An, R.; Gao, H.; Yu, S. Estimation and allocation of the benefits from electricity market integration in China Energy Clim. Chang. 2021, 2, 100054. [CrossRef]

36. Gallaher, A.; Graziano, M.; Fiaschetti, M. Legacy and shockwaves: A spatial analysis of strengthening resilience of the power grid in Connecticut. Energy Policy 2021, 159, 112582. [CrossRef]

37. Huang, J.; Xiang, S.; Wu, P.; Chen, X. How to control China's energy consumption through technological progress: A spatial heterogeneous investigation. Energy 2021, 238, 121965. [CrossRef]

38. Zhao, P.-J.; Zeng, L.-E.; Lu, H.-Y.; Zhou, Y.; Hu, H.-Y.; Wei, X.-Y. Green economic efficiency and its influencing factors in China from 2008 to 2017: Based on the super-SBM model with undesirable outputs and spatial Dubin model. Sci. Total Environ. 2020, 741, 140026. [CrossRef] [PubMed]

39. Moreno, R.; Paci, R.; Usai, S. Spatial Spillovers and Innovation Activity in European Regions. Environ. Plan. A Econ. Space 2005, 37, 1793-1812. [CrossRef]

40. Baicker, K. The spillover effects of state spending. J. Public Econ. 2005, 89, 529-544. [CrossRef]

41. Griliches, Z. Patent Statistics as Economic Indicators: A Survey; National Bureau of Economic Research: Cambridge, MA, USA, 1990. [CrossRef]

42. Lanjouw, J.O.; Pakes, A.; Putnam, J. How to Count Patents and Value Intellectual Property: The Uses of Patent Renewal and Application Data. J. Ind. Econ. 1998, 46, 405-432. [CrossRef]

43. Dechezleprêtre, A.; Glachant, M.; Haščič, I.; Johnstone, N.; Ménière, Y. Invention and Transfer of Climate Change-Mitigation Technologies: A Global Analysis. Rev. Environ. Econ. Policy 2011, 5, 109-130. [CrossRef]

44. Harhoff, D.; Scherer, F.M.; Vopel, K. Citations, family size, opposition and the value of patent rights. Res. Policy 2003, 32, 1343-1363. [CrossRef]

45. Klaassen, G.; Miketa, A.; Larsen, K.; Sundqvist, T. The impact of R\&D on innovation for wind energy in Denmark, Germany and the United Kingdom. Ecol. Econ. 2005, 54, 227-240. [CrossRef]

46. Peters, M.; Schneider, M.; Griesshaber, T.; Hoffmann, V.H. The impact of technology-push and demand-pull policies on technical change-Does the locus of policies matter? Res. Policy 2012, 41, 1296-1308. [CrossRef]

47. Nemet, G.F. Inter-technology knowledge spillovers for energy technologies. Energy Econ. 2012, 34, 1259-1270. [CrossRef]

48. Anselin, L.; Bera, A.K.; Florax, R.; Yoon, M.J. Simple diagnostic tests for spatial dependence. Reg. Sci. Urban Econ. 1996, 26, 77-104. [CrossRef]

49. Hausman, J.; Hall, B.; Griliches, Z. Econometric Models for Count Data with an Application to the Patents-RED Relationship; National Bureau of Economic Research: Cambridge, MA, USA, 1984. [CrossRef] 
50. Jaumotte, F.; Pain, N. From Ideas to Development: The Determinants of RED and Patenting; OECD Publishing: Paris, France, 2005. [CrossRef]

51. Hall, B.; Griliches, Z.; Hausman, J. Patents and RED: Searching for a Lag Structure; National Bureau of Economic Research: Cambridge, MA, USA, 1983. [CrossRef]

52. Acemoglu, D.; Aghion, P.; Bursztyn, L.; Hemous, D. The Environment and Directed Technical Change. Am. Econ. Rev. 2012, 102, 131-166. [CrossRef]

53. Lahiani, A.; Mefteh-Wali, S.; Shahbaz, M.; Vo, X.V. Does financial development influence renewable energy consumption to achieve carbon neutrality in the USA? Energy Policy 2021, 158, 112524. [CrossRef]

54. Zhou, S.; Tong, Q.; Pan, X.; Cao, M.; Wang, H.; Gao, J.; Ou, X. Research on low-carbon energy transformation of China necessary to achieve the Paris agreement goals: A global perspective. Energy Econ. 2021, 95, 105137. [CrossRef] 